\title{
PENGARUH MOTIVASI TERHADAP KINERJA PEGAWAI SMP NEGRI 18 BANDAR LAMPUNG
}

\author{
Tety $^{(1)}$, Fahrizi ${ }^{(2)}$, Khairul Saleh ${ }^{(3)}$ \\ Fakultas Ekonomi Universitas Sang Bumi Ruwa Jurai \\ tety1234@gmail.com,fahrizi@fe.saburai.ac.id, khairul.saleh@fe.saburai.ac.id
}

\begin{abstract}
Abstrak.Objek Penelitian adalah SMP Negri 18 Bandar Lampung berlokasi dijalan Rasuna Said No. 29, Gulak Galik, Teluk Betung Utara Kota Bandar Lampung. Objek penelitian ini termasuk ke dalam SMP terfavorit di Kota Bandar Lampung. Motivasi menjadi pendorong seseorang melaksanakan suatu kegiatan guna mendaptkan hasil yang baik. Permasalahan pada penelitian ini yaitu: pegawai yang tidak disiplin, lingkungan kerja yang kurang nyaman serta kepemimpinan yang tidak tegas. Penelitian ini bertujuan untuk mengetahui seberapa besar pengaruh motivasi kerja terhadap kinerja pegawai di SMP N 18 Bandar Lampung. Metode penelitian ini menggunkaan metode kuantitatif dengan menggunakan 65 responden.

Pengumpulan data penelitian ini menggunakan teknik populasi dari seluruh pegawai di SMP N 18 Bandar Lampung. Berdasarkan analisis, maka dapat disimpulkan hipotesis yang diajukan adalah :"ada hubungan antara Motivasi kerja dengan Kinerja pegawai di SMP N 18 Bandar Lampung". Hasil dari penelitian ini adalah adanya pengaruh antara motivasi kerja terhadap kinerja pegawai sebesar $1.7 \%$, hasil ini berdasarkan koefesien determinasi sisanya sebesar 98,3\% lainnya adalah dipengaruhi oleh faktor lain.
\end{abstract}

Kata Kunci: Motivasi, Kinerja, Pegawai.

\section{PENDAHULUAN}

Pendidikan adalah modal dasar untuk menciptakan Sumber Daya Manusia yang kreatif dan inovatif.Dunia pendidikan yang utama adalah sekolah.Sekolahsebagai suatu lembaga tentunya memiliki visi, misi, tujuan dan fungsi.

Untuk mengemban misi, mewujudkan visi, mencapai tujuan, dan menjalankan fungsinya SMP N 18 Bandar Lampung perlu mengembangkan suatu cara agarmampu menciptakan suatu lembaga pendidikan yang dapatmenyelenggarakan pendidikan sesuai harapan bagi masyarakat luas.

Untukmelakukan hal ini tentu bukan hal yang mudah, tetapi memerlukan kerjakeras dan dorongan individu untuk melakukan tindakan dalam mencapai tujuan,yaitu motivasi kerja. Apabila pegawai termotivasi, maka pegawai akan membuatpilihan yang positif untuk melakukan sesuatu pekerjaan dengan baik dan benar,karena dapat memuaskan keinginannya. Edwin B. Flippo dalam Hasibuan(2003:143) mendefinisikan motivasi adalah suatu keahlian dalam mengarahkanpegawai dan organisasi agar mau bekerja secara berhasil, sehingga keinginanpara pegawai dan tujuan organisasi sekaligus tercapai.

Pada dasarnya motivasi dapat memacu pegawai untuk bekerja keras sehingga dapat mencapai tujuan pokok organisasi atau institusi pendidikan.

Hal ini akan meningkatkan kualitas kinerja yaitu motivasi kerja. Pegawai yang memiliki motivasi kerja yang tinggi, senantiasa mempunyai semangat ataudorongan untuk bekerja keras, sebagai energi guna membangkitkan dorongan dalam diri sehingga mencapai prestasi, disamping itu hal ini disebabkan merekamemiliki pengendali diri yang baik maka tidak memerlukan pengawasanyang 
ketat dalam mencapai kinerja yang maksimal.

Pegawai akan merasa terbebani jika pegawai tidak dapat bekerja dengan baik untuk dapat mempertahankan prestasi yang telah dimiliki oleh intansi, makadari itu kinerja pegawai tidak akan menghasilkan hasil yang maksimal jikapegawai tidak memiliki motivasi kerja yang tinggi dalam melaksanakan tugastugasnya. Seperti yang dikatakan Mangkunegoro (2009 : 66) kinerja adalah kerjasecara kualitas dan kuantitas, yang dicapai oleh seorang pegawai dalammelaksanakan tugasnya sesuai dengan tanggung jawab yang diberikankepadanya.

Berdasarkan hasil pengamatan di lokasi penelitian ini yang akandilakukan di SMP N 18 Bandar Lampung yang beralamat dijalan Rasuna SaidNo.18 Sumur Batu, Tanjung Karang Timur. penulis menemukan beberapapegawai munujukkan tidak seluruh pegawai yang memiliki motivasi kerjayang tinggi untuk berprestasi dalam bekerja. Hal ini dapat dilihat dari beberapapegawai yang masih bermalasmalasan dalam melaksanakan pekerjaan yangdiberikan. Seperti yang kita ketahui ada beberapa hal yang dapat membangkitkanmotivasi kerja pegawai diantaranya gaji yang cukup, upah yang layak, suasanakerja yang menyenangkan, kesempatan untuk berkembang, kebutuhan akanpengetahuan dan kesempatan berprestasi. Namun salah satu kendala yangdihadapi pegawai SMP N 18 Bandar Lampung yang didominan oleh pegawaiialah kurangnya kedasaran akan kedisiplinan masing-masing, seperti pada saatjam masuk kerja dan jam pulang kerja yang tidak teratur, banyaknya berkas yangtidak rapih pada ruang staf masngmasing, dan banyak pula pegawai yang seringmelewatkan meeting pagi.

Dapat dilihat hal tersebut diatas tentu saja mengakibatkan menurunnya semangat kerja pegawai.Pegawai yang tidak memiliki motivasi dalam bekerjatentu tidak dapat melakukan pekerjaan dengan baik. Dengan demikian dapatdisimpulkan bahwa rendahnya motivasi kerja akan berdampak pada rendahnyahasil kinerja.

Berdasarkan uraian diatas, maka peneliti tertarik untuk melakukan penelitian mengenai motivasi kerja dan kinerja, dengan judul "Pengaruh Motivasi Kerja Terhadap Kinerja Pegawai SMP N 18 Bandar Lampung"

\section{KAJIAN TEORI}

\section{Pengertian Motivasi}

Motivasi berasal dari kata dalam bahasa latin yakni movere yang berarti dorongan atau menggerakkan. Semua perilaku manusia biasanya didasari akanmotivasi atau dorongan dalam banyak hal yang menyebabkan mereka berperilaku demikian. Pada manajemen, motivasi adalah hal yang menyebabkan semua anggota organisasi untuk bekerja dalam menyelesaikan pekerjaan yang sesuai motif atau tujuan organisasi atau perusahan yang ingin dicapai.

Menurut Siagian dalam Kartika (2010:102) definisi dari motivasi adalah keseluruhan proses pemberian motif bekerja kepada para bawahan sedemikian rupa sehingga mereka mau bekerja dengan ikhlas demi tercapainya tujuan organisasi dengan efisien dan ekonomis. As'ad dalam Roesyadi (2012:24) mengemukakan bahwa motivasi sering sekali diartikan sebagai dorongan. Dorongan atau tenaga tersebut merupakan gerak jiwa dan jasmani untuk berbuat sehingga motivasi tersebut merupakan driving force yangmenggerakkan manusia untuk bertingkah laku di dalam perbuatannya itu mempunyai tujuan tertentu.

Adapun motivasi sebagai keadaan dimana usaha dan kemauan keras seseorang 
diarahkan kepada pencapaian hasil-hasil atau tujuan tertentu.Hasil-hasil yang dimaksud bisa berupa produktivitas, kehadiran atau perilaku kerja kreatif lainnya (Sopiah, 2008-170).

\section{Metode Motivasi}

Teori motivasi yang menjelaskan bagaimana pemberian motivasi yakni ada dua metode pemberian motivasi yang lazim dipakai yaitu :

\section{Motivasi langsung (direct motivation)}

Motivasi langsung adalah motivasi (materiil dan non-materiil) yang diberikansecara langsung kepada setiap individu karyawan untuk memenuhi kebutuhanserta kepuasannya.Jadi sifatnya khusus, seperti pujian, penghargaan, tunjanganhari raya, bonus, bintang jasa dan lainnya.

\section{Motivasi tidak langsung (indirect} motivation)

Motivasi tidak langsung adalah motivasi yang diberikan hanya merupakan fasilitas-fasilitas yang mendukung serta menunjang gairah kerja atau kelancarantugas sehingga para karyawan betah dan bersemangat melakukan pekerjaannya.Misalnya, kursi yang empuk, suasana pekerjaan yang nyaman dan lainnya.Motivasi tidak langsung besar pengaruhnya untukmerangsang semangat bekerja karyawan agar produktif. (Robbins, 2001)

\section{Kinerja Karyawan}

Kinerja dalam organisasi merupakan jawaban dari berhasil atau tidaknyatujuan organisasi yang telah ditetapkan.Para atasan atau manajer sering tidak memerhatikan kecuali sudah amat buruk atau segala sesuatu jadi serba salah.Terlalu sering manajer tidak mengetahui betapa buruknya kinerja telah merosot sehingga perusahaan/ instansi menghadapi krisis yang serius.Kesan-kesan buruk organisasi yang mendalam berakibat dan mengabaikan tanda-tanda peringatan adanya kinerja yang merosot.

Kinerja sebagai hasil-hasil fungsi pekerjaan/atau kegiatan seseorang ataukelompok dalam suatu organisasi yang di pengaruhi oleh berbagai faktor untuk mencapai tujuan organisasi dalam periode waktu tertentu (Tika, 2006:26).Kinerja dapat diartikan sebagai gambaran mengenai tingkat pencapaian pelaksanaan suatu kegiatan atau program, atau kebijakan dalam mewujudkan sasaran, tujuan, misi dan visi organisasi yang tertuang dalam rencana strategi suatu organisasi.Istilah kinerja sering digunakan untuk menyebut prestasi atau tingkat keberhasilan individu atau kelompok individu.Kinerja dapat diketahui hanya jika individu atau kelompok individu tersebut memiliki kriteria keberhasilan yang telah ditetapkan.Kriteria keberhasilan ini berupa tujuan-tujuan atau target-target tertentu yang hendak dicapai.Tanpa adanya tujuan serta target, kinerja seseorang atau organisasi tidak dapat diketahui karena tidak ada tolok ukurnya.

Kinerja adalah hasil kerja yang dapat dicapai oleh seseorang atausekelompok orang dalam suatu organisasi, sesuai dengan wewenang dan tanggung jawab masing-masing, dalam upaya mencapai tujuan organisasi bersangkutan secara legal, tidak melanggar hukum dan sesuai dengan moral maupun etika. Sementara itu Mangkunegara (2008:9) mengemukakan bahwa "kinerja adalah hasil kerja secara kualitas dan kuantitas yang dicapai oleh karyawan dalam melaksanakan tugasnya sesuai dengan tanggungan yang diberikan kepadanya".Selanjutnya menurut Wilson bangun (2012:230) yang menjelaskan 
bahwa "sistem manajemenkinerja atau performance management system merupakan proses untuk mengidentifikasi, mengukur dan mengevaluasi kinerja karyawan dalam perusahaan”.

Sesungguhnya semua organisasi atau perusahaan memiliki sarana

sarana formal dan informal untuk menilai kinerja pegawainya. Penilaian kinerja atau prestasi kerja (performance appraisal) adalah proses suatu organisasi mengevaluasi atau menilai prestasi kerja pegawai. Kegiatan ini dapat memengaruhi keputusan-keputusan personalia dan memberikan umpan balik kepada para pegawai tentang pelaksanaan kerja mereka (Handoko, 2007:135).

Dari berbagai uraian tentang kinerja pegawai yang telah dijelaskan dapatdisimpulkan bahwa kinerja pegawai merupakan hasil kerja yang dapat dicapai seseorang atau sekelompok orang dalam suatu organisasi sesuai wewenang dan tanggung jawab masing-masing untuk mewujudkan tujuan organisasi.

\section{Pengukuran Kinerja}

Adanya beberapa pendapat yang membahas tentang pengukuran kinerjaakan dijadikan dasar untuk menentukan indikator dari variabel kinerja yang telah dipaparkan diatas. Dua syarat yang harus dipenuhi agar pengukuran kinerja berjalan dengan efektif yaitu, adanya kriteria kinerja yang dapat diukur secara objektif dan adanya objektivitas dalam pengukuran. Maka dapat disimpulkan sebagai standar penilaian adalah :

Menurut Mangkunegara (2001:18) aspek-aspek standar kinerja terdiri dari aspek kuantitatif dan kualitatif.

1. Aspek kualitatif

a. Proses kerja dan kualitas pekerjaan

b. Waktu yang digunakan untuk menyelesaikan pekerjaan c. Jumlah kesalahan dalam melaksanakan pekerjaan

d. Jumlah dan jenis pemberian pelayanan dalam bekerja

2. Aspek kualitatif

a. Ketetepan kerja dan kualitas pekerjaan

b. Tingkat kemampuan dalam pekerjaan

c. Kemampuan dalam menganalisis data/informasi dan kemampuan menggunakan mesin/peralatan.

\section{Penilaian Kinerja}

Penilaian kinerja menurut Murwansyah dalam managemen sumber dayamanusia adalah system formal untuk memeriksa atau mengkaji dan mengevaluasi kinerja seseorang atau kelompok.

Kinerja adalah pencapaian/prestasi seseorang berkenaan dengan tugas-tugas yang dibebankan kepadanya. Kinerja dapat pula dipandang sebagai panduan dari hasil kerja (apa yang harus dicapai oleh seseorang) dan kopetensi (sebagaimana seseorang mencapainya). Penilaian pegawai merupakan evaluasi yang sistematis dari pekerjaan pegawai dan potensi yang dapat dikembangkan. Penilaian adalah proses penaksiran atau penentuan nilai, kualitas, atau status dari beberapa objek, orang ataupun sesuatu.

Menurut Handoko (2009:135), mengatakan bahwa penilaian kinerja dapat digunakan untuk :

1. Perbaikan kinerja, umpan balik pelaksanaan pekerjaan kerja memungkinkan pegawai dapat memperbaikinya untuk meningkatkan prestasi.

2. Perencanaan kebutuhan latihan dan pengembangan, kinerja yang jelek mungkin menunjukan perlunya latihan. Demikian juga sebaliknya, kinerja yang baik mungkin mencerminkan potnsi yang harus dikembangkan. 
3. Menditeksi kesalahan-kesalahan pekerjaan, kinerja yang jelek mungkin merupakan suatu tanda kesalahan dalam pekerjaan. Penilaian kinerja membantu mendiagnosa kesalahan-kesalahan tersebut.

4. Melihat tantangan-tantangan eksternal, kadang-kadang prestasi seseorang dipengaruhi oleh faktor-faktor diluar lingkungan kerja, seperti keluarga, kesehatan dan masalah-masalah pribadi lainnya.

Berdasarkan kriteria diatas, maka dapat dikatakan bahwa penilaian kinerja adalahsuatu proses penilaian kinerja pegawai yang dilakukan pimpinan secara sistematis berdasarkan pekerjaan yang ditugaskan kepadanya.

\section{METODE PENELITIAN}

\section{Objek Penelitian}

Objek penelitian ini adalah pada SMP N 18 Bandar Lampung yang berada di Jalan Rasuna Said No.29, Gulak Galik, Teluk Betung Utara KotaBandar Lampung.

\section{Variabel Penelitian Dan Definisi Variabel Oprasional}

Variabel penelitian adalah suatu atribut atau sifat atau nilai dari orang atau objek yang mempunyai variasi antara satu dengan yang lainnya dalam kelompok itu (Sugiyono, 2002). Berdasarkan telaah pustaka dan perumusan hipotesis, maka variabel-variabel dalam penelitian ini adalah :

\section{Variabel Bebas (Independen)}

Variabel bebas atau independen merupakan variabel yang mempengaruhi ataumenjadi sebab timbulnya atau berubahnya variabel dependen (variabel terikat). Dalam penelitian ini yang merupakan variabel bebasnya adalah motivasi kerja (Sugiyono, 2002).

\section{Variabel Terikat (Dependen)}

Variabel terikat atau dependen merupakan variabel yang dipengaruhi atau yangmenjadi akibat karena adanya variabel bebas (independen). Dalam penelitian ini yang merupakan variabel terikatnya adalah kinerja Pegawai (Sugiyono,2002).

\section{Metode dan Teknik Pengumpulan Data}

Terdapat dua cara untuk mengumpulkan data yang akan diperlukan untukmelakukan analisis dalam penelitian ini, yaitu sebagai berikut :

\section{Pengumpulan Data Primer}

Pengumpulan data primer dalam penelitian ini dilakukan dengan menggunakan teknik sebagai berikut :

\section{a. Kuesioner}

Teknik pengumpulan data yang digunakan dalam penelitian iniadalah teknik pengumpulan data dengan menggunakan kuesioner. Kuesioner adalah teknik pengumpulan data yang dilakukan dengan cara memberiseperangkat pertanyaan atau pernyataan tertulis kepada responden untuk dijawab. Kuesioner merupakan teknik pengumpulan data yang efisien bila peneliti tahu dengan pasti variable yang akan diukur dan tahu apa yang bisa diharapkan dari responden.

\section{Pengumpulan Data Sekunder}

Data sekunder diperoleh dari data yang diberikan oleh perusahaan, sepertistruktur organisasi dan sejarah perusahaan. Skala yang digunakan dalam penelitian ini adalah skala Likert.

Menurut Ghozali (2006), skala Likert adalah skala yang berisi 5 tingkat 
preferensi jawaban dengan pilihan sebagai berikut :

1 = Sangat tidak setuju

$2=$ Tidak setuju

$3=$ Cukup

$4=$ Setuju

$5=$ Sangat setuju

\section{Sampel dan Populasi}

Menurut Sugiyono (2013), populasi adalah wilayah generalisasi yang terdiri atas subyek atau obyek yang mempunyai kualitas dan karakteristik tertentu yangditetapkan oleh peneliti untuk dipelajari dan kemudian ditarik kesimpulannya.Populasi digunakan untuk menyebutkan seluruh elemen dari suatu wilayah yangmenjadi sasaran penelitian atau merupakan keseluruhan (universum) dari obyekpenelitian (Noor, 2012).Populasi dalam penelitian ini adalah karyawan SMPN 18Bandar Lampung.

Tabel 1.Jumlah Pegawai di SMP N 18 Bandar Lampung

\begin{tabular}{|c|c|c|}
\hline No & Pegawai & Jumlah \\
\hline 1. & Guru & 42 \\
\hline 2. & Staf & 17 \\
\hline 3. & $\begin{array}{c}\text { Penjaga } \\
\text { gedung }\end{array}$ & 6 \\
\hline & Jumlah & 65 \\
\hline
\end{tabular}

Penentuan sampel dilakukan dengan menggunakan Probability Sampling yaitu menggunakan Simple Random Sampling. Menurut Sugiyono (2013), SimpleRandom Sampling adalah pengambilan anggota sampel dari populasi dilakukansecara acak tanpa memperhatikan strata yang ada dalam populasi tersebut, olehkarena itu sampel pada riset ini adalah karyawan yang bekerja di SMPN 18Bandar Lampung.

\section{Metode Analisis Data}

Dalam penelitian ini, hasil pengumpulan data beruapa hasil penyebarankuisoner kepada pegawai, kemudian akan diolah (melakukan uji statistic) denganmenggunakan beberapa teknik atau metode uji statistik, antara lain :

a. Validitas

b. Realibitas

Dimana uji validitas menggunakan rumus correlation productmoment dan uji realibitas ini menggunakan metode Cronbach (Alpha/Realibity analysis).

\section{Uji Validitas}

Pengujian Validitas ini dapat dilakukan dengan mengunakan rumus sebagai berikut:

$$
\frac{\mathrm{n} \sum x y-\sum x \cdot \sum y}{\sqrt{\left[\left(n \sum x^{2}\right)-\left(\sum x\right)^{2} \cdot\left(n \sum y^{2}\right)-\left(\sum y\right)^{2}\right]}}
$$

\section{Keterangan:}

$\mathrm{r}=$ Korelasi Product Moment

$\mathrm{X}=$ Variabel Bebas

$\mathrm{Y}=$ Variabel Terikat

Dalam penelitian ini, uji validitas dilakukan dengan menggunakan bantuan program SPSS(Statistcal Program and Service Solution) 20.0 dengan kriteriapengujian:

1. Jika nilai rhitung> rtabelmaka kuisioner dinyatakan valid.

2. Jika nilai rhitung < rtabel maka kuisioner dinyatakan tidak valid.

\section{Uji Realibitas}

Pengujian realibitas ini dapat digunakan dengan menggunakan rumus sebagai berikut :

$$
r_{I I}=\left(\frac{k}{k-1}\right)\left(1-\frac{\sum \sigma b^{2}}{\sigma t^{2}}\right)
$$




\section{Keterangan :}

$\mathrm{r}_{\mathrm{II}}=$ Reliabilitas instrumen

$\Sigma \sigma b^{2}=$ Jumlah varians butir

$\Sigma \sigma \mathrm{t}^{2}=$ Variasi total

\section{Uji Regresi Sederhana}

Regresi digunakan untuk menelaah hubungan antara dua variabel atau lebih, terutama untuk menelusuri pola hubungan yang modelnya belum diketahui dengan sempurna, atau untuk mengetahui bagaimana variabel independen berpengaruh terhadap variabel dependen dalam suatu fonomena yang komplek.

Persamaan regresi digunakan untuk menguji signifikasi pengaruh variabel bebas (Motivasi Kerja) terhadap variabel terikat (Kinerja Pegawai).

Secara umum persamaan regresi dapat dirumuskan sebagai berikut :

$$
Y=a+b X
$$

\section{Keterangan :}

$\mathrm{Y}=$ Nilai yang diprediksikan

$\mathrm{a}=$ kostanta

$\mathrm{b}=$ Koefesien Regresi

$\mathrm{X}=$ Nilai Variabel independen

\section{Uji T}

Uji t pada dasarnya menunjukan seberapa jauh pengaruh satu variabelindependen secara individual menerangkan variasi terikat (Ghozali, 2006).Pengujian Parsial regresi dimaksutkan untuk untuk mengetahui apakah variabelbebas secara individual mempunyai pengaruh terhadap variabel terikat dengan asumsi variabel yang lain itu konstans.
Untuk melakukan pengujian $\mathrm{t}$ maka dapat digunakan rumus sebagai berikut :

$$
t=\frac{\beta n}{s \beta n}
$$

\section{keterangan :}

$\mathrm{t}$ : mengikuti fungsi $\mathrm{t}$ dengan derajat kebebasan (df)

$\beta \mathrm{n}$ : Koefesien Masing-Masing

$\mathrm{S} \beta \mathrm{n}$ : Stabdar Eror masing-masing Variabel

\section{HASIL DAN PEMBAHASAN}

\section{Uji Validitas Instrumen}

Uji Validitas digunakan untuk mengukur sah atau valid tidaknya suatukuisoner. Suatu kuisoner diikatakan valid jika pertanyaan pada kuisoner mampu untuk mengungkapkan sesuatu yang akan diukur oleh kuisoner tersebut.

Pengujian validitas dalam penelitian ini menggunakan person correlationyaitu dengan cara menghitung korelasi antara lain yang diperoleh dari pertanyaan pertanyaan dengan bantuan software SPSS. Kriteria valid atau tidak adalah jika korelasi antara skor masing-masing butir pertanyaan dengan total skor mempunyai tingkat signifikansi di bawah 0,05 maka butir pertanyaan tersebut dapat dikatakan valid, dan jika korelasi skor masing-masing butir petanyaan dengan total skor mempunyai tingkat signifikansi di atas 0,05 maka butir pertanyaan tersebut tidak valid (Ghozali, 2011).

Tabel Uji Validitas Motivasi Kerja (X)

\begin{tabular}{|c|c|c|c|}
\hline No & Rxy & Rtabel & Keterangan \\
\hline 1 & 0.354 & 0.2441 & Falid \\
\hline 2 & 0.555 & 0.2441 & Falid \\
\hline 3 & 0.443 & 0.2441 & Falid \\
\hline 4 & 0.257 & 0.2441 & Falid \\
\hline 5 & 0.378 & 0.2441 & Falid \\
\hline
\end{tabular}


\begin{tabular}{l|l|l|l|}
6 & 0.392 & 0.2441 & Falid \\
\hline
\end{tabular}

Berdasarkan tabel diatas, kriteria item atau butir instrument pada variabelmotivasi $(\mathrm{X})$ adalah jika $r$ hitung $>r$ tabel, maka item atau butir instrument dinyatakan valid, sedangkan jika $r$ htung $<r$ tabel maka item atau butir instrumentdinyatakan tidak valid. Nilai $\mathrm{r}$ tabel di dapat dari perhitungan $\mathrm{df}=\mathrm{dk}-\mathrm{n}=65$ $-2=63$ dengan taraf signifikan $0,05 \%$. Maka didapatlah $r$ tabel sebesar 0,2441.

Tabel Uji Validitas Kinerja Pegawai (Y)

\begin{tabular}{|c|c|c|c|}
\hline No & Rxy & Rtabel & Keterangan \\
\hline 1 & 0.502 & 0.2441 & Valid \\
\hline 2 & 0.247 & 0.2441 & Valid \\
\hline 3 & 0.284 & 0.2441 & Valid \\
\hline 4 & 0.363 & 0.2441 & Valid \\
\hline 5 & 0.536 & 0.2441 & Valid \\
\hline 6 & 0.487 & 0.2441 & Valid \\
\hline 7 & 0.408 & 0.2441 & Valid \\
\hline 8 & 0.244 & 0.2441 & Valid \\
\hline
\end{tabular}

Berdasarkan tabel di atas, kriteria item atau butir instrument pada variabelkinerja (Y) adalah jika $\mathrm{r}$ hitung $>\mathrm{r}$ tabel, maka item atau butir pertanyaan tersebut dinyatakan valid, sedangkan $r$ hitung < r tabel maka dinyatakan tidak valid. Nilai $r$ tabel di dapat dari perhitungan $\mathrm{df}=\mathrm{dk}-\mathrm{n}=65-2=63$ dengan taraf signifikan $0,05 \%$ maka didapat nilai $\mathrm{r}$ tabel sebesar 0,2441.

\section{Uji Realibitas} kemudian dilanjutkan dengan pengujianrealibitas data.Pengujian ini dilakukan untuk menganalisa data/instrumen penelitian, berupa butirbutir pertanyaan (kuisoner), apakah realibel atau tidak realibel.Metode yang digunakan dalam pengujian realibitas data ini menggunakan Cronbach Alpha. Instrumen penelitian yang realibel berati bahwa instrument tersebut dapat digunakan beberapa kali untuk mengukur objek yang sama.

Pengujian realibitas ini dilakukan terhadap butir-butir pertanyaan (kuisoner)dengan melihat nilai $\mathrm{r}$ (alpha Realibitas) merupakan sesuatu instrument cukup dapat dipercaya untuk digunakan sebagai alat pengumpulan data karena instrumen tersebut sudah baik (Suharsimi Arikunto, 2006: 178).Kriteria pengujian instrument dikatakan realibel apabila rhitung > rtabel pada taraf signifikansi $5 \%$.Jika instrument realiabel berdasarkan uji coba, maka instrument tersebut dapat digunakan sebagai instrument pengumpulan data.

Hasil perhitungan uji realibitas pada penelitian ini dapat diinterprestasikan sebagai berikut :

Tabel Uji Reabilitas Motivasi Kerja (X) Reliability Statistic

\begin{tabular}{|r|r|}
\hline $\begin{array}{c}\text { Cronbach's } \\
\text { Alpha }^{\mathrm{a}}\end{array}$ & $\begin{array}{c}\text { N of } \\
\text { Items }\end{array}$ \\
\hline .380 & \\
\hline
\end{tabular}

Berdasarkan tabel diatas, maka nilai Cronbach's Alpha 0,380 > r tabel 0,2441 menandakan bahwa instrumen realibitas karena sudah memenuhi batas 0,50 (0.52 > 0.50) sehingga dapat digunakan sebagai bahan penelitian selanjutnya.

Tabel Uji Reabilitas Kinerja Pegawai (Y) Reliability Statistic

\begin{tabular}{|r|r|}
\hline $\begin{array}{c}\text { Cronbach's } \\
\text { Alpha }^{\mathrm{a}}\end{array}$ & $\begin{array}{c}\mathrm{N} \text { of } \\
\text { Items }\end{array}$ \\
\hline .378 & 8 \\
\hline
\end{tabular}

Berdasarkan tabel diatas, nilai Cronbach Alpha 0,378> r tabel 0,2441menandakan bahwa instrument realibel karena sudah memenuhi batas 0,50 $(0,378>0,50)$ sehingga dapat digunakan untuk penelitian selanjutnya. 


\section{Uji Regresi Sederhana}

Tabel Hasil Perhitungan Regresi Linier Sederhana

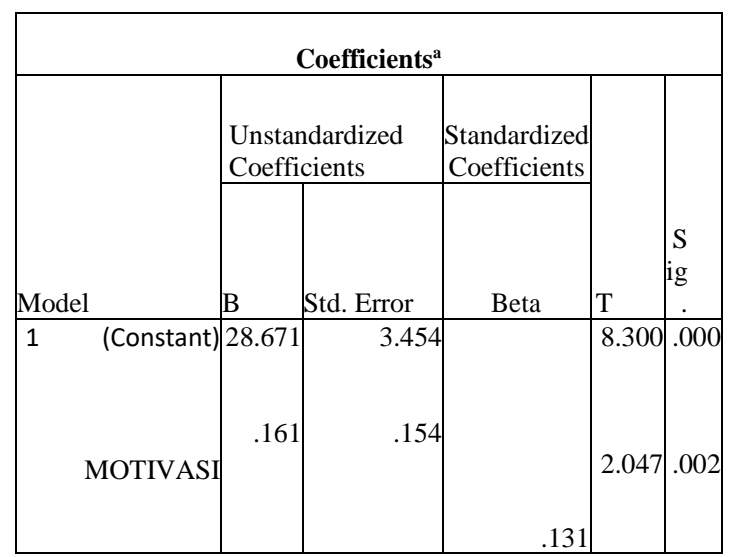

\section{Keterangan :}

$\mathrm{X}=$ Motivasi

$\mathrm{Y}=$ Kinerja Pegawai (KP)

a. Konstanta sebesar 28.671 artinya jika motivasi (X) nilainya 0 , maka tingkat kinerja pegawai $(\mathrm{Y})$

b. Koefesien Regresi sebesar 0.161 artinya Motivasi (X) nilainya 0 , makatingkat kinerja pegawai (Y) mengalami peningkatan sebesar 0.161 .

\section{Uji T}

Dasar pengambilan keputusan Uji T :

A. Jika nilai sig $<0.05$ atau $t_{\text {hitung }}>t_{\text {tabel }}$ maka terdapat pengaruh variabel $\mathrm{X}$ terhadap variabel $\mathrm{Y}$

B. Jika nilai sig $>0.05$, atau $F_{\text {hitung }}<F_{\text {tabel }}$ maka tidak terdapat pengaruh variabel $\mathrm{X}$ secara simultan terhadap variabel $\mathrm{Y}$.

$$
\begin{aligned}
T_{\text {tabel }} & =t(a / 2 ; n-k-1) \\
& =t(0.025 ; 64) \\
& =1.999
\end{aligned}
$$

\section{KESIMPULAN DAN SARAN}

\section{Kesimpulan}

Berdasarkan hasil penelitian tentang pengaruh motivasi terhadap kinerjapegawai di SMP N 18 Bandar Lampung, maka peneliti menymipulkan yangberdasarkan penjelasan dan paparan bahasanya sebelumnya, yaitu :

a. Besarnya pengaruh motivasi kerja terdapat kinerja pegawai di SMP $\mathrm{N}$ 18Bandar Lampung sebesar 1,7\%, hasil inididapat berdasarkan uji koefesiendeterminasi sisanya sebesar $98,3 \%$, lainnya adalah dipengaruhi oleh faktorlain.

b. Berdasarkan hasil perhitunganmenenjukan bahwa persamaan regresilinier, yaitu Y: Y: $28.671+0.161 X$, artinya nilai konstanta sebesar 28.671artinya jika motivasi $(\mathrm{X})$ nilainya 0 , maka tingkat kinerja pegawai (Y)sebesar 28.671. koefisien regresi sebsar 0.161 , artinya motivasi (x)nilainya 0 , maka tingkat kinerja pegawai (Y) mengalami peningkatansebesar 0.161 .

\section{Saran}

Berdasarkan kesimpulan yang telah dipaparkan diatas, maka penelitimenyampaikan bebrapa saran terkait permasalahan dalam penelitian ini,yaitu:

a. Untuk mencapai kinerja pegawai yang baik dibutuhkan fasilitas yang lenihbaik maupun sarana kerja dalam ruangan pegawai, temperature udara yangbaik dan lingkungan kerja yang bersih menunjang seluruh kinerja pegawaiyang berada di SMP N 18 Bandar Lampung.

b. Kinerja pegawai di SMP N 18 Bandar Lampung perlu dimaksimalkan danmemperbaiki kualitas kinerjanya denganmelakukan pelatihan 
danpendidikan pegawai baik itu Nitisemito, Alex, S. 2006. Manajemen Suatu informal maupun formal.

c. Gaya kepemiminan di lingkungan SMP N 18 bandar Lampung agar lebihdiperbaiki hubungannya dengan semua pegawai dengan tepat, kumunikasiyang baik dengan semua bawahan dan juga memberikan contoh yang baikkepada semua pegawai di SMP N 18 Bandar Lampung.

\section{DAFTAR PUSTAKA}

A.A. Anwar Prabu Mangkunegara. 2009. Dasar dan Pengantar.Penerbit PT Ghalia Indoensia. Jakarta

Notoatmodjo. 2009. Pengembangan Sumber Daya Manusia. Jakarta :Rineka Cipta

Prasetya, Bambang, dkk. 2010. Metodologi Penelitian Kualitatif. Jakarta: PT. Raja Grafindo

Rivai, Veithzal. 2006. Manajemen Sumber Daya Manusia Untuk Perusahaan. Jakarta: Raja Grafindo Indonesia.

Managemen SumberDaya Manusia.

Bandung. PT. Remaja Rosdakarya1212

Arikunto, Prof. Dr. Saharsimi. 2006. Prosedur Penelitian Suatu Pendekatan Praktik. $P R$. Jakarta: Rineka Cipta.

Handoko, T. Hani. 2001. Manajemen Sumber Daya Manusia. Yogyakarta : BPFE. Yogyakarta

Hariandja, Marihot Tua Effendi. 2002. Manajemen Sumber Daya Manusia, Jakarta: PT Gramedia Widiasarana.

Hasibuan, Malayu, S,P. 2009. Manajemen Sumber Daya Manusia dan kunci keberhasilan.Penerbit CV Haji. Jakarta: Masagung.

Manullang, M. 2000. Manajemen Personalia Jakarta: PT Ghalia Indonesia.

Mulyadi - Pratinju. 2007. Sistem Perencanaan dan Pengendalian Manajemen. Jakarta: Selemba Empat.

Nazir, Moh. 2005. Metode Penelitian. Ghalia Indonesia. Bogor. 